\title{
Corrigendum
}

\section{Caspase-2 deficiency promotes aberrant DNA-damage response and genetic instability}

\author{
L Dorstyn, J Puccini, CH Wilson, S Shalini, M Nicola, S Moore and S Kumar
}

Cell Death and Differentiation (2012) 19, 1411. doi:10.1038/cdd.2012.76

Correction to: Cell Death and Differentiation (2012) 19, 1288-1298; doi:10.1038/cdd.2012.36; published online 13 April 2012

Since the publication of this article, the authors have noticed that in Figure $5 d$ the number of metaphases counted for $\mathrm{E} \mu \mathrm{Myc} / \mathrm{Casp} 2^{-/-}$should be 51 , not as incorrectly stated as 50 .

This error has now been rectified and the correct article appears in this issue. The html and online pdf versions have also been rectified, and now carry the correct paper.

The authors apologize for any inconvenience caused. 